\title{
MORPHOLOGICAL CHARACTERISTIC AND PHENETIC RELATIONSHIP OF Lysurus periphragmoides COLLECTED FROM WEST JAVA
}

\section{Rudy Hermawan ${ }^{1 *}$, Laifa Fusvita ${ }^{2}$, Naufal Hafizh Nugraha ${ }^{3}$, Mega Putri Amelya ${ }^{4}$}

Received : December 31, 2020

Accepted : April 29, 2021

DOI: 10.15575/biodjati.v6i1.10724

1,2,3,4 Department of Biology, Faculty of Mathematics and Natural Sciences, IPB University, Jl. Agatis Kampus IPB Dramaga, Bogor, 16680, Indonesia

e-mail:

*1hermawan_rudy@apps.ipb.ac.id

2evafusvita19@gmail.com

3nhafizh43@gmail.com

흐ega_amelya@apps.ipb.ac.id

*Corresponding author

\begin{abstract}
Lysurus is one of the unique genera in Basidiomycetes. It has a stinky odor and slime on the head. The unusual-shaped makes the species in Lysurus easily to be identified. One of Lysurus had been found in West Java, Indonesia namely L. periphragmoides. The specimen was deposited into Herbarium Bogoriense with code BO 24418. This study aimed to obtain specimens and characterize the Lysurus BO 24418 using morphological characteristics, and analyze the phenetic relationship among Lysurus species. Lysurus BO 24418 has two phases (egg and mushroom). The egg phase is usually hypogeous underground. The mushroom has a head and stem. The head bears the mature spore with slime distribute malodor. The stem has a hollow and spongy texture with a yellowish color. The numerical data of morphological characters of species in Lysurus were analyzed using NTSys ver 2.1 software. Ten characters were used to build a dendrogram using Sequential Agglomerative Hierarchical Nested (SAHN) cluster analysis with Unweighted Pair Group Method with Arithmetic Mean (UPGMA). Phallus indusiatus was selected as an outgroup. The analyses showed the specimen was classified as L. periphragmoides with 100\% of similarity coefficient and it was close L. gardneri with $40.4 \%$ of similarity coefficient. The characters that cluster among them are stem surface, head type, egg diameter, and spore max length.
\end{abstract}

Keywords: dendrogram, numerical data, stinkhorn mushroom, unusual mushroom

\section{Citation}

Hermawan, R., Fusvita, L., Nugraha, N. H. \& Amelya, M. P. (2021). Morphological Characteristics and Phenetic Relationship of Lysurus periphragmoides Collected from West Java. Jurnal Biodjati, 6(1), 102-110.

\section{INTRODUCTION}

Stinkhorn fungi are a unique mushroom group that has original characters, such as smelly and unusual-shaped. They begin the first stage being mushroom through eggshaped structure underground. The size is similar to a golf ball. The egg phase largely consists of immature spores with many layers (membrane) inside. Sitinjak (2016) observed and reported the development of egg phase of Phallus indusiatus. Membrane from the top has mucus from the inner crevices torn part. Then, the egg will grow to emerge a coat from under the hood (cap). That process takes about 2 hours (usually between 7 to $9 \mathrm{am}$ ).

The second stage is being a real mushroom appeared on the ground and best known 


\section{JURNAL BIDDJATI}

http://journal.uinsgd.ac.id/index.php/biodjati

for looking like horns or penis structure. Literally, sometimes it is like an empty ball, or octopus (Caffot et al., 2018). The mature part of the fruiting body contains a spore coated by slime. The cap bearing the slime and spores is held for 4 to 5 hours. The slime produces a stinky smell and making flies or other insects come and touch the spore, then distribute to other objects and places.

The stinkhorn fungi belongs to Phallales order, but not all of the family containing the stinkhorn fungi (Hosaka et al., 2006). Phallales was invented by E. Fischer in 1898. (Hosaka et al., 2006) mentioned that the Phallales equivalent to Phallales sensu Kirk et al. (2008), and also the gomphoid-phalloid clade (Hibbet \& Thorn, 2001). (Hosaka et al., 2006) classified the family in Phallales into Clathraceae, Phallaceae, Lysuraceae, Protophallaceae, Claustulaceae and Trappeaceae. The study categorized the stinkhorn fungi are in the Clathraceae, Phallaceae, and Lysuraceae. Lots of research on the basis of exploration were reported many kinds of stinkhorn fungi (Long, 1907; Lopez \& Garcia, 2012; Sitinjak, 2016; Verma et al., 2016). Many reports of the mushroom specifically about the name were often the mistake or unclear. One of the problems was on Lysurus periphragmoides.

This mushroom had the unclearly status for the description (Kuo, 2019e). Kuo mentioned the description of 2 different mushroom specimens but categorized it as the same species Lysurus periphragmoides. Then, a publication from Caffot et al. (2018) continued to clear status of $L$. periphragmoides and correct the name, description, and specimen. Caffot et al. (2018) confirmed and checked many specimens of Lysurus species molecularly, especially L. periphragmoides. Now, the status between the name of Lysurus species and specimens have been clearly described.
The fruiting body for the Lysurus is rarely found and seasonable. The unique morphology of Lysurus makes them easily to identify. The morphological characters can be studied for phenetic relationship among the species. Currently, the study of phenetic relationship among Lysurus species is not available yet. In this study, the phenetic relationship was studied comprehensively. Fortunately, the fruiting body for the $L$. periphragmoides had been found in Indonesia. The description based on the morphological characteristic was conducted in this study to enrich the mega data about L. periphragmoides.

\section{MATERIALS AND METHODS}

\section{Site and Time of Sampling and Experiment}

The sampling to collect fruiting bodies of stinkhorn fungus (Lysurus periphragmoides) was conducted from January to March 2017, which were in the rainy season. The exploration located in the Arboretum of IPB University, West Java, Indonesia. The sampling site was specifically around the litter and debris of the plant. The experiment to characterize the fruiting body was conducted at the Mycology Laboratory, Biology Department, Mathematics and Natural Science Faculty, IPB University.

\section{Mushroom Sampling}

Mushroom sampling was started by searching the fruiting bodies upper and around the litter and debris. The mushrooms should be fruiting bodies that has the Lysurus characteristics (Kuo, 2019a; 2019b; 2019c; 2019d; 2019e; 2019f), such as smelly, horn-shaped, yellowish stem and the gleba or cap with a hole. The condition and characters of the fruiting bodies were recorded. The important characters of fruiting body such as shape, cap shape, stem shape, and spores were observed 


\section{JURNAL BIDDJATI}

http://journal.uinsgd.ac.id/index.php/biodjati

and documented. The fruiting bodies were preserved in FAA (Kottapalli et al., 2016) and deposited into Herbarium Bogoriense, LIPI, Indonesia.

\section{Numerical Analysis of Morphological Data}

All of the morphological data from the fruiting body were prepared to be numerical data. Other morphological data from (Kuo, 2019a; 2019b; 2019c; 2019d; 2019e; 2019f) about other specimens of Lysurus (L. mokusin, L. sphaerocephalum, L. gardneri, L. cruciatus, L. corallocephalus, L. periphragmoides) were also transferred into numerical data. The morphological characters used 10 characters which were converted into binary data (Table 1), namely stem surface, head shape, head type, stem color, head color, egg diameter, stem diameter, stem height, head ornament, and maximum spore length. The data were analyzed using cluster Numerical Taxonomy and Multivariate Analysis System (NTSys) version 2.1 software. The dendrogram was generated using mixed data with Unweighted Pair Group Method with Arithmetic Mean (UPGMA) and Sequential Agglomerative Hierarchical Nested (SAHN) cluster analysis with Phallus indusiatus (Kuo, 2011) as an outgroup. The similarity coefficient at the point of taxa separation was presented in a dendrogram.

Table 1. Morphological characters and numerical data used for numerical analysis

\begin{tabular}{|c|c|c|c|c|c|c|c|c|}
\hline \multirow[b]{2}{*}{ Characters } & \multicolumn{7}{|c|}{ Lysurus (Species) } & \multirow{2}{*}{$\begin{array}{c}\text { Outgroup } \\
\text { Phallus } \\
\text { indusiatus }\end{array}$} \\
\hline & $\begin{array}{c}\text { L. } \\
\text { mokusin }\end{array}$ & $\begin{array}{c}L . \\
\text { sphaerocephalum }\end{array}$ & $\begin{array}{c}L . \\
\text { gardneri }\end{array}$ & $\begin{array}{c}\text { L. } \\
\text { cruciatus }\end{array}$ & $\begin{array}{c}\text { L. } \\
\text { corallocephalus }\end{array}$ & $\begin{array}{c}L . \\
\text { periphragmoides }\end{array}$ & $\begin{array}{c}L . \\
\text { periphragmoides } \\
\text { in this study }\end{array}$ & \\
\hline Stem surface & 2 & 1 & 3 & 1 & 1 & 3 & 3 & 1 \\
\hline Head shape & 1 & 4 & 1 & 2 & 3 & 4 & 4 & 5 \\
\hline Head type & 1 & 1 & 1 & 2 & 2 & 1 & 1 & 1 \\
\hline Stem color & 4 & 3 & 1 & 2 & 2 & 2 & 2 & 1 \\
\hline Head color & 4 & 4 & 1 & 3 & 4 & 2 & 2 & 1 \\
\hline Egg diameter & 1 & 1 & 2 & 1 & 3 & 2 & 2 & 5 \\
\hline Stem diameter & 2 & 3 & 3 & 1 & 2 & 4 & 4 & 5 \\
\hline Stem height & 1 & 2 & 2 & 1 & 2 & 1 & 1 & 4 \\
\hline Head ornament & 0 & 0 & 0 & 0 & 0 & 0 & 0 & 1 \\
\hline $\begin{array}{l}\text { Maximum } \\
\text { spore length }\end{array}$ & 3 & 2 & 4 & 2 & 3 & 5 & 5 & 1 \\
\hline
\end{tabular}

Note: The catagories of numerical data are shown in attachment 1.

\section{RESULTS AND DISCUSSION}

\section{Morphological Characteristics of Lysurus periphragmoides}

The fruiting body found was 2 mature fruiting bodies (real mushroom) and 2 immature fruiting bodies (egg phase) (Figure 1). The specimen was deposited into Herbarium Bogoriense, Indonesia, with the code BO 24418. Lysurus periphragmoides looks like a spongy microphone. It has two phases i.e. egg and mushroom phase. The egg phase is white to yellowish color with rhizoid and $4.2-4.8 \mathrm{~cm}$ in diameter. The egg is hypogeous. A part of eggs sometimes epigeous when the egg grows into mature stage. This phase will be matured by a head of the mushroom that appeared from the top of the egg. That part is then open and broken the skin of the egg. Odor has been smelled since the 


\section{JURNAL BIDDJATI}

http://journal.uinsgd.ac.id/index.php/biodjati

egg's broken until a mushroom appeared.

Egg phase. Egg white to yellowish (Figure 2a); hypogeous but sometimes the upper part epigeous; smooth; sub globose to ovoid; diameter $4.2-4.8 \mathrm{~cm}$; short rhizoid under the egg. Mature mushroom. Stem pale white to yellowish (Figure 2b); hollow inside the stem (Figure 2c) and inside the wall (Figure 2d); the surface free of ornament, waving, longitudinally grooved (Figure $2 \mathrm{e}$ ); spongy texture; volva whitish and mucus out; $6.7-7.4 \mathrm{~cm}$ long; diam. $2.6-2.9 \mathrm{~cm}$. Head rounded but sometimes looks like a ball (Figure 2f); diameter $3.4-4.2 \mathrm{~cm}$; yellow when the slime out; bearing dark brown slime; malodor; some holes around the surface like polygonal-shaped with diameter $0.2-0.3$ $\mathrm{cm}$; the surface zigzag structure (Figure $2 \mathrm{~g}$ ).
Spore. Basidiospore ellipsoid and rounded at the end shaped (Figure 2h); free ornament; hyalin; $3.2-5.0 \times 1.8-2.2 \mu \mathrm{m}$.

The mushroom has two parts i.e. stem and head. Stem is yellowish and spongy-textured. The stem is hollow inside. Then, the stem wall has a hollow pattern of thickness. The stem surfaces from outside and inside are different. The outside has longitudinally grooved patterns. The inside has small wavy patterns. The stem has $6.7-7.4 \mathrm{~cm}$ long and $2.6-2.9 \mathrm{~cm}$ in diameter. The head has ballshaped with some holes around the head. The structure of the hole is arranged by a zig-zagpatterned on the surfaces. The head bears slime with spores. The odor from slime attracts flies to come and touch the head. The head is attached directly to the stem apex.

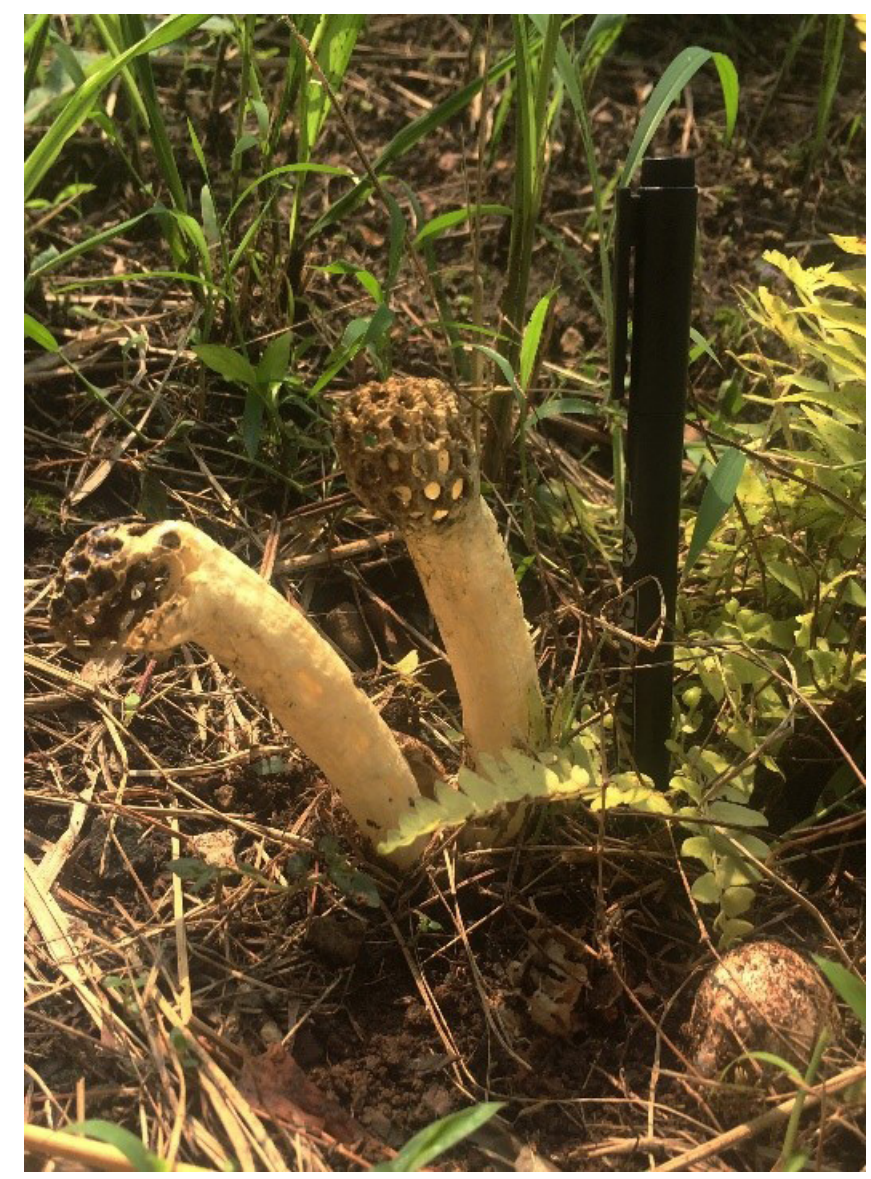

Figure 1. Fruiting bodies of Lysurus periphragmoides. (pen is $10 \mathrm{~cm}$ long) 


\section{JURNAL BIDDJATI}

http://journal.uinsgd.ac.id/index.php/biodjati

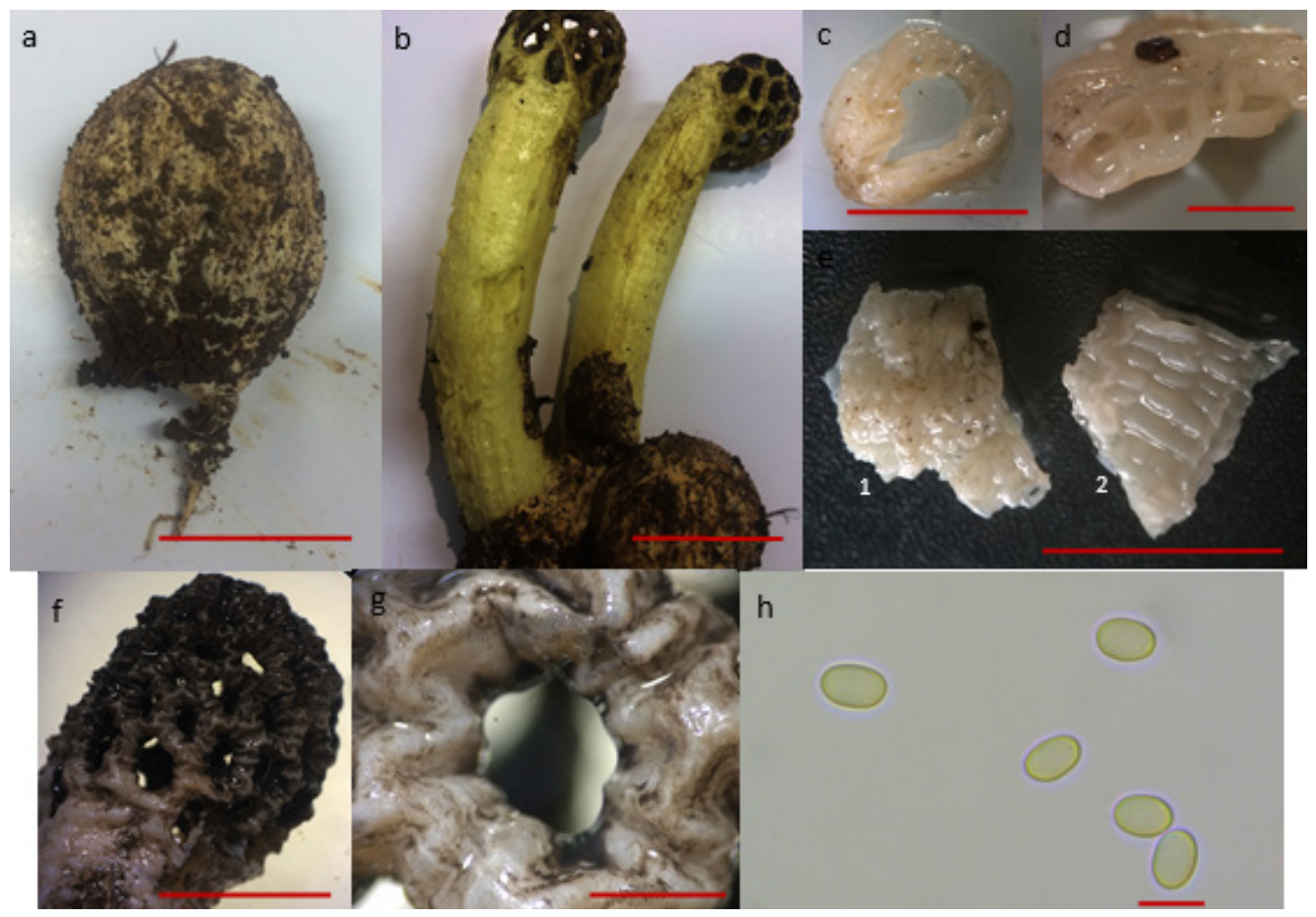

Figure 2. Morphology of L. periphragmoides. a) Egg phase; b) Stem; c) slicing of stem horizontally; d) slicing of stem wall horizontally; e) surface (1) inside stem, (2) outside stem; f) head; g) hole of head part; h) basidiospores. Scale of bar: a, b, c, e, and f = $3 \mathrm{~cm}$; $=1 \mathrm{~cm} ; \mathrm{h}=5 \mathrm{~cm}$.

The Lysurus BO 24418 has different shape of immature and mature fruiting body. The mushroom description is really important to collect the immature (young) and mature fruiting bodies. (Hermawan et al., $2020 \mathrm{~b}$ ) found the different morphology for same the mushroom namely Chlorophyllum molybdenum. The difference is about the cap shape of immature and mature fruiting bodies. Other mushrooms such as Trichaleurina javanica (Hermawan et al., 2020a), and Sphaerobolus stellatus (Hermawan \& Maulana, 2020) are also showed different shape among their phases.

Lysurus is known as lantern stinkhorn or the small lizard's claw or the ribbed lizard claw. Currently, Lysurus has six species (Kuo, 2019a; 2019b; 2019c; 2019d; 2019e; 2019f). However, 32 species are mentioned in (Index Fungorum, 2021) i.e. L. arachnoideus,
$L$. archeri, L. argentinus, $L$. aseroeformis, L. australiensis, L. beauvaisii, L. borealis, L. brahmagirii, L. brevipes, L. clarazianus, L. congolensis, L. corallocephalus, L. cruciatus, L. garciae, L. gardneri, L. habungianus, L. hardyi, L. kawamurensis, L. mokusin, L. muellerianus, L. pakistanicus, L. pentactinus, L. pentagonus, L. periphragmoides, L. pusillus, L. sanctae -catharinae, L. sinensis, L. sphaerocephalum, L. sulcatus, L. tenuis, L. texensis, and L. woodii. Many of the species were described which the specific shape of fruiting bodies. The species that has complete descriptions are L. periphragmoides, L. mokusin, L. sphaerocephalum, L. corralocephalum, L. cruciatus, and L. gardneri. This study found the $L$. periphragmoides from Indonesia. In the previous studies, the species was in debate of name and description between 


\section{JURNAL BIDDJATI}

http://journal.uinsgd.ac.id/index.php/biodjati

L. periphragmoides and L. sphaerocephalum that were ambiguous for the correct description. Actually, both of them have the different fruiting body where L. periphragmoides has a bigger head than L. sphaerocephalum. The names among them were confusing before Caffot et al. (2018) published the article that decided the correct name and description of them. Caffot et al. (2018) studied and clarified the correct description among $L$. periphragmoides and L. sphaerocephalum specimen using a phylogenetic tree.

Lysurus had the old name Simblum. There are two Simblum species that had been reported previously, i.e. S. sphaerocephalum (Schlechtendal, 1861) and S. periphragmoides (Klotzsch, 1831). The description of both Simblum were described based on the morphology of fruiting bodies (Conard, 1913). The misunderstanding about the description was continued after discovering their fruiting body. The fruiting bodies were almost similar when the egg phase and the young mushroom. It makes some researchers were wrong to naming the Lysurus species. Furthermore, $S$. periphragmoides was transferred to Lysurus in 1980.

The Lysurus was built by Fries in 1823 . Dring made the key to identified Lysurus until the species. Based on Dring, this genus was really close to Aseroe. The characters from Aseroe that separate Lysurus were "Arms attached to the margin of a flat discoid expansion of the stipe apex, diverging, with gleba on the upper surface of arms or disc or both". The characters only appeared a Aseroe. Whereas Lysurus had "fertile portion a lattice or short, erect, paired columns". The separation between Aseroe and Lysurus also was strongly mentioned in Hosaka et al. (2006) which was based on the molecular study. Aseroe was classified into Clathraceae, whereas Lysurus into Lysuraceae.
This study found L. periphragmoides. the status of this species is clear in the description of the fruiting body. Our specimen has been matching with the specimen's characters in Caffot et al. (2018). Now, the description is completely available, but the DNA of $L$. periphragmoides was not really avai-lable such as in Caffot et al. (2018) (only available for RPB2) and in our specimen. The status of L. periphragmoides should be completed as soon as possible. Not only for L. periphragmoides, but also for other Lysurus species. The mega data should be built and submitted to the GenBank.

\section{Phenetic Relationship of $L$. periphragmoides with Other Members of Lysurus}

Analysis of overall similarity of unweighted 10 binary data set in SAHN method indicates that specimen BO 24418 forms a good cluster and classifies as L. periphragmoides at coefficient similarity of about $100 \%$ (Figure 3). Analysis of overall similarity of unweighted 10 binary data set in SAHN method indicates that L. Periphragmoides specimen is exactly same to L. Periphragmoides from Kuo specimen. Then, L. Periphragmoides is close to L. gardneri with a $40.4 \%$ similarity coefficient (Figure 3). The characters that may be matched among them are stem surface, head type, egg diameter, and spore max length. Within Lysurus cluster, there are two clades separated by three distinct characters i.e. the stem surface, egg diameter, and spore max length. This dendrogram supposed to be able to separate the Lysurus in species. The dendrogram that built by morphological data were also studied by Khan et al. (2011) and Ekowati et al. (2011) to separated Pleurotus species. Based on Khan et al. (2011), the comparison between the dendrogram built by morphological data and molecular data was 


\section{JURNAL BIDDJATI}

http://journal.uinsgd.ac.id/index.php/biodjati

not really different for the branching and pattern of the species distribution. The important thing is a good and clear morphology. There- fore, it can be really used to identify them into species.

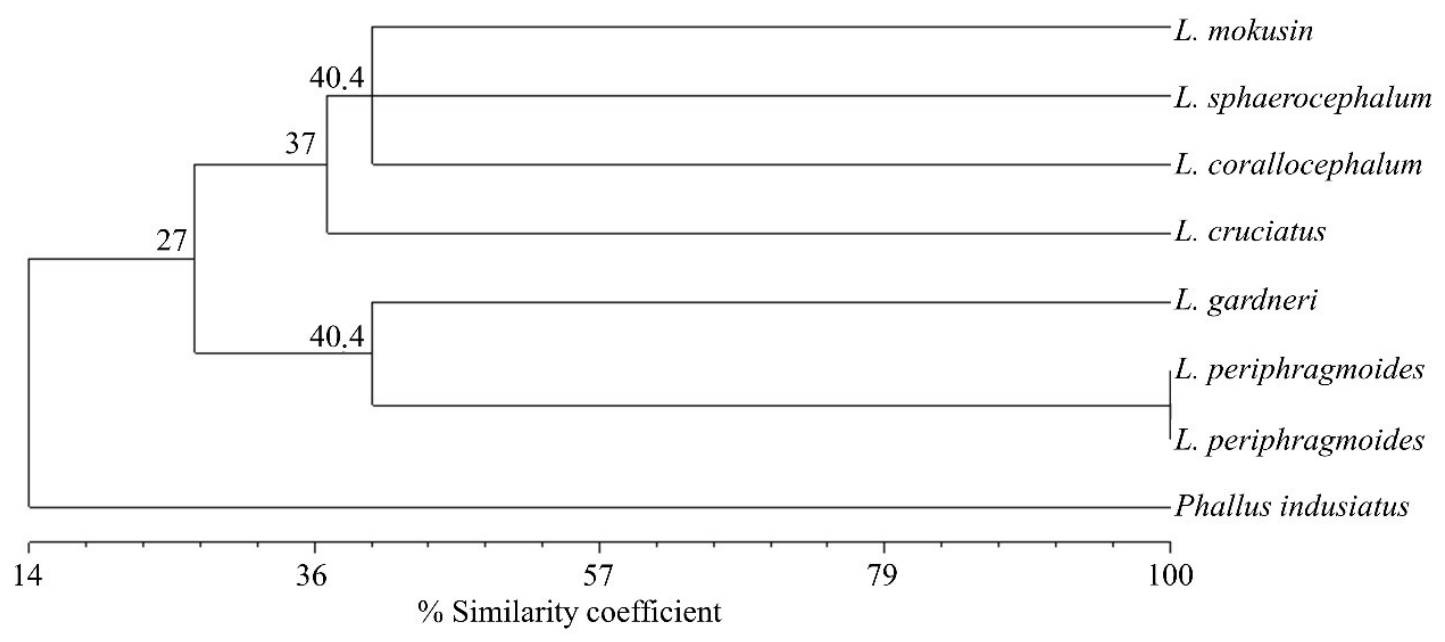

Figure 3. Dendrogram of Lysurus species using SAHN method with Unpair Group with Arithmatic Mean parameter. Relationship is expressed as similarity coefficient.

\section{ACKNOWLEDGEMENTS}

The authors say thanks to Indra Maulana for the assistance in this research and to Herbarium Bogoriense LIPI Indonesia for helping the herbarium preservation.

\section{REFERENCES}

Caffot, M. L. H., Hosaka, K., Dominguez, L. S. \& Urcelay, C. (2018). Molecular and Morphological Data Validate the New Combination of Lysurus sphaerocephalum from Argentina, with Some Additional Records on Phallales (Agaricomycetes). Mycologia, 110(2), 419-433.

Conard, H. S. (1913). The Structure of Simblum sphaerocephalum. Mycologia, 5(5), 264-273.

Ekowati, N., Kasiamdari, R. S., Pusposendjojo, N. \& Soegihardjo, C. J. (2011). Hubungan Kekerabatan Fenetik Jamur
Shiitake (Lentinula edodes (Berk.) Pegler) berdasarkan Karakter Morfologi. Biosfera, 29(1), 110-117.

Hermawan, R., Amelya, M. P. \& Julia, Z. R. (2020a). Trichaleurina javanica from West Java. Jurnal Mikologi Indonesia, 4(2), 175-181.

Hermawan, R., Imaningsih, W. \& Badruzsaufari. (2020b). Mushrooms Assumed as Ectomycorrhizal Fungi on South Kalimantan Serpentine Soil. Jurnal Mikologi Indonesia, 4(1), 149-155.

Hermawan, R. \& Maulana, I. (2020). Sphaerobolus stellatus: Cannonball Mushroom from West Java. Jurnal Mikologi Indonesia, 4(2), 218-222.

Hibbet, D. S. \& Thorn, R. G. (2001). Basidiomycota: Homobasidiomycetes. In The Mycota. Vol VII. Part B. Systematics and Evolution. Springer-Verlag.

Hosaka, K., Bates, S. T., Beeer, R. E., Castellano, M. A., Colgan III, W., Dominguez, L. S., Nouhra, E. R., Geml, J., Giachi- 


\section{JURNAL BIDDJATI}

http://journal.uinsgd.ac.id/index.php/biodjati

ni, A. J., Kenney, S. R., Simpson, N. B., Spatafora, J. W. \& Trappe, J. M. (2006). Molecular Phylogenetics of the Gomphoid-phalloid Fungi with an Establishment of the new subclass Phallomycetidae and two new orders. Mycologia, 98(6), 949-959.

Index Fungorum. (2021). Lysurus. Retrieved from http://www.indexfungorum.org/ Names/Names.asp

Khan, S. M., Nawaz, A., Malik, waqas, Javed, N., Yasmin, T., Rehman, M. ur, Qayyum, A., Iqbal, Q., Ahmad, T. \& Khan, A. A. (2011). Morphological and Molecular Characterization of Oyster Mushroom (Pleurotus spp.). African Journal of Biotechnology, 10(14), 2638-2643.

Kirk, P. M., Cannon, P. F., Minter, D. W. \& Stalpers, J. A. (2008). Dictionary of the fungi (10th ed.). CAB International.

Klotzsch, F. J. (1831). Simblum periphragmoides.Botanical Miscellany, 2, 164-165.

Kottapalli, S., Krishna, H., Venumadhav, K., Nanibabu, B., Jamir, K., Ratnamma, B. K., Jena, R. \& Babarao, D. K. (2016). Preparation of Herbarium Specimen for Plant Identification and Voucher Number. Roxburghia, 6, 111-119.

Kuo, M. (2011). Phallus Indusiatus. Retrieved from https://www.mushroomexpert.com/phallus_indusiatus.html

Kuo, M. (2019a). Lysurus corallocephalus. Retrieved from https://www.mushroomexpert.com/lysurus corallocephalus.html

Kuo, M. (2019b). Lysurus crusiatus. Retrieved from https://www.mushroomexpert.com/lysurus_cruciatus.html
Kuo, M. (2019c). Lysurus gardneri. Retrieved from https://www.mushroomexpert. com/lysurus_gardneri.html

Kuo, M. (2019d). Lysurus mokusin. Retrieved from https://www.mushroomexpert. com/lysurus_mokusin.html

Kuo, M. (2019e). Lysurus periphragmoides. Retrieved from https://www.mushroomexpert.com/lysurus_periphragmoides.html

Kuo, M. (2019f). Lysurus species 01. Retrieved from https://www.mushroomexpert.com/lysurus_species_01.html

Long, W. H. (1907). The Phalloideae of Texas. Mycological Bulletin, 5(79), 335-342.

Lopez, A. \& Garcia, J. A. (2012). Lysurus periphargmoides. Funga Veracruzana, 132.

Schlechtendal, D. F. L. Von. (1861). Eine Neue Phalloidee, Nebst Bemerkungen Uber Die Ganae Familie Derselben. In Diverse Berichte (pp. 101-194). Retrieved from https://www.zobodat.at/pdf/ Zeitschrift-fuer-Botanik 13 I-CDXXIV.pdf

Sitinjak, R. R. (2016). Analysis of the morphology and growth of the fungus Phallus indusiatus Vent. in Cocoa Plantation, Gaperta-Ujung Medan. Research Journal of Pharmaceutical, Biological and Chemical Sciences, 7(6), 442-449

Verma, R. K., Verma, P. \& Mishra, Y. (2016). Headless Stinkhorn Fungi (Mutinus spp.) with Special Reference to Indian Species. Indian Journal of Tropical Biodiversity, 24(1), 75-80. 


\section{JURNAL BIDDJATI}

http://journal.uinsgd.ac.id/index.php/biodjati

\section{ATTACHMENT}

Stem Surface:

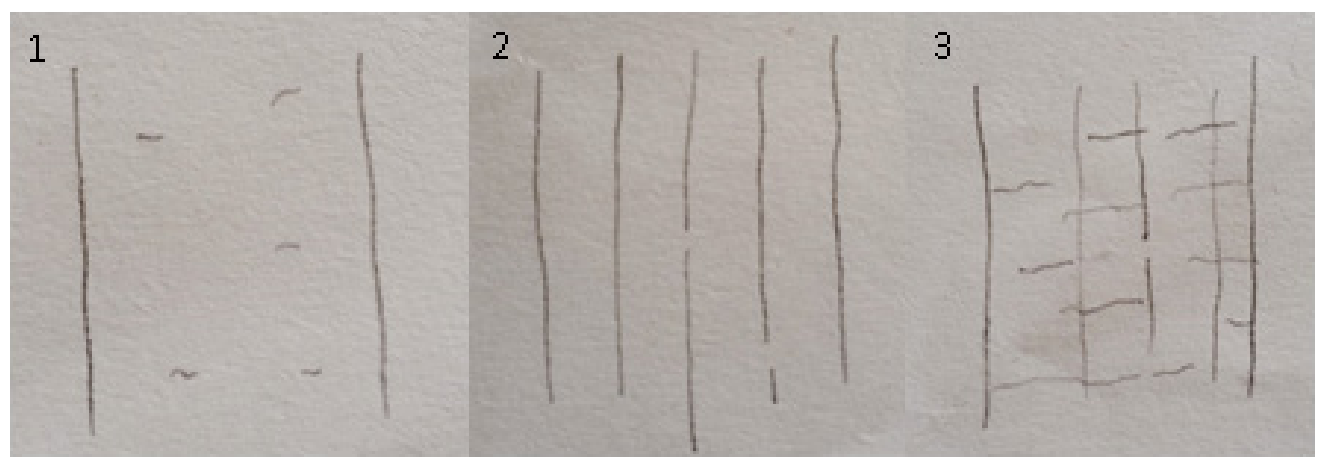

Head Surface:

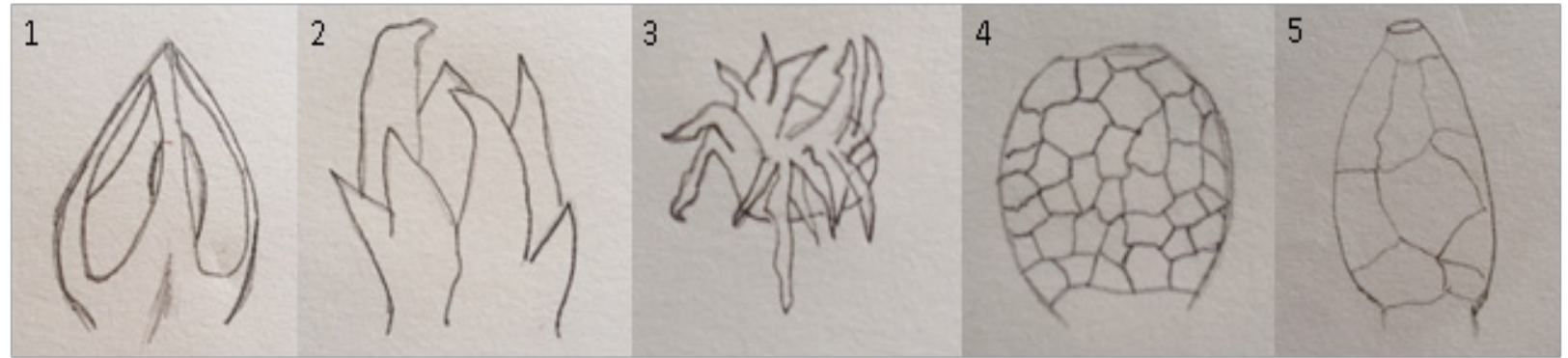

Head type:
(1) Opened
(2) Closed

Stem color:
(1) White
(2) Yellowish
(3) Orange
(4) Red

Cap color:
(1) White
(2) Yellowish
(3) Orange
(4) Red

Stem diameter:
(1) $2 \mathrm{~cm}$
(2) $3 \mathrm{~cm}$
(3) $4 \mathrm{~cm}$
(4) $5 \mathrm{~cm}$
(5) $6 \mathrm{~cm}$

Stem diameter:
(1) $1 \mathrm{~cm}$
(2) $1,5 \mathrm{~cm}$
(3) $2 \mathrm{~cm}$
(4) $2,5 \mathrm{~cm}$
(5) $3 \mathrm{~cm}$

Stem height:
(1) $5.01-10.00 \mathrm{~cm}$
(2) $10.01-15.00 \mathrm{~cm}$
(3) $15.01-20.00 \mathrm{~cm}$
(4) $20.01-25.00 \mathrm{~cm}$

Head ornament:

(1) Free of ornament (2) Ornamented

Maximum spore length:
(1) $3.01-3.50 \mathrm{~cm}$
(2) $3.51-4.00 \mathrm{~cm}$
(3) $4.01-4.50 \mathrm{~cm}$
(4) $4.51-5.00 \mathrm{~cm}$ 